\title{
PRORAČUN PROTUPOŽARNE OTPORNOSTI DRVENIH KONSTRUKCIJA PREMA EURONORMI
}

\author{
Ivana Barić \\ Sveučilište Josipa Jurja Strossmayera u Osijeku, Građevinski fakultet Osijek, student \\ Tihomir Štefić \\ Sveučilište Josipa Jurja Strossmayera u Osijeku, Građevinski fakultet Osijek, asistent \\ Stjepan Takač \\ Sveučilište Josipa Jurja Strossmayera u Osijeku, Građevinski fakultet Osijek, prof.dr.sc.
}

Sažetak: Ovaj rad daje sažet prikaz proračuna protupožarne otpornosti drvenih konstrukcija prema Eurokodu 5 (EC5), tj. prema normi EN 1995-1-2. Ova norma objašnjava načela, zahtjeve i pravila proračuna drvenih poprečnih presjeka, elemenata, spojeva, zidnih i podnih sklopova izloženih požaru. Također, definira doprinos protupožarnoj otpornosti drvenih konstrukcijskih dijelova u slučaju primjene pasivne protupožarne zaštite. U radu će biti objašnjene dvije metode proračuna po normi EN 1995-1-2, metoda proračunskog poprečnog presjeka i metoda redukcije svojstava. Osim toga, biti će prikazan i način proračuna protupožarne otpornosti poprečnog presjeka na proračunskom modelu drvene proste grede.

Ključne riječi: EN 1995-1-2, požar, protupožarna otpornost, dubina pougljenja, metoda proračunskog poprečnog presjeka, metoda redukcije svojstava.

\section{DESIGN OF FIRE RESISTANCE OF TIMBER STRUCTURES ACCORDING TO EUROCODE}

\begin{abstract}
This paper gives a concise overview of structural fire design of timber structures according to Eurocode 5 (EC5), i.e. according to EN 1995-1-2 standard. This standard describes the principles, requirements and rules for the structural desing of timber cross-sections, elements, connections, wall and floor assemblies exposed to fire. It also defines procedures which determine the contribution to fire resistance of timber structural components when passive fire protection is applied. In the paper two design methods according to norm EN 1995-1-2, reduced cross-section method and reduced properties method are explained. Besides that, a fire resistance of a timber cross-section for a simply supported beam is shown.
\end{abstract}

Key words: EN 1995-1-2, fire, fire resistance, charring depth, reduced cross-section method, reduced properties method. 


\section{Uvod}

Da bi se mogao razumjeti način protupožarnog proračuna drvenih konstrukcija, potrebno je znati požarne karakteristike drva. Kod drva se razlikuju dvije faza požara, požar u nastanku i puni požar. Požar u nastanku ne karakterizira vatra koja zahvaća sve zapaljive materijale pa je u ovoj fazi važno koliko iznosi stupanj sagorijevanja i intenzitet provođenja topline drva te kolika je brzina širenja vatre po površini. Za razliku od požara u nastanku, puni požar predstavlja fazu nakon „vatrenog skoka“ (predstavlja istovremeno zapaljenje svih zapaljivih materijala u zatvorenom prostoru). Stoga je u ovoj fazi mjerodavna nosivost drva te njegova mogućnost da ograniči širenje vatre kako ne bi došlo do prijenosa požara na susjedna područja. Drvo ima vrlo dobre požarne karakteristike pa se često uspoređuje s ostalim materijalima. Na primjer, drvo u slučaju požara prenosi 10 puta slabije toplinu isijavanja nego beton i 250 puta slabije nego čelik. Stvarne vrijednosti svojstava zapaljivosti ovise o gustoći, vrsti i vlažnosti drva te odnosu obujma i presjeka elementa.

Postoje tri kriterija ponašanja drva u požaru pri čemu elementi moraju zadovoljiti sva tri kriterija. Kriterij nosivosti R podrazumijeva da se konstrukcija mora proračunati i izvoditi tako da zadrži svojstvo nosivosti tijekom odgovarajuće izloženosti požaru. Kriterij integriteta konstrukcije E pokazuje svojstvo sprječavanja prolaza plamena i vrućih plinova. Kriterij izolacije I ispunjen je ako prosječan porast temperature na cijeloj neizloženoj površini ne prelazi vrijednost od 140K ili na bilo kojem dijelu vrijednost od $180 \mathrm{~K}$.

\section{Opća analiza konstrukcije}

Opće pravilo koje konstrukcija mora zadovoljiti je da proračunska vrijednost djelovanja $E_{d, f i}$ mora biti manja ili jednaka vrijednosti pripadajuće proračunske otpornosti $R_{d, t, f i}\left(E_{d, f i} \leq R_{d, t, f i}\right)$. $E_{d, f i}$ je reducirano proračunsko djelovanje $E_{d}$ koje vrijedi u uvjetima obične temperature. Redukcija se vrši tako da se proračunsko djelovanje pomnoži s faktorom redukcije opterećenja tijekom požara $\eta_{\mathrm{f} .}$ Osim što norma EN 1995-1-2 daje izraz za $\eta_{\mathrm{fi}}$, na slici 1 se može vidjeti način očitavanja faktora redukcije $\eta_{f i}$ ovisno o faktoru kombinacije $\psi_{f i}$ i o omjeru $Q_{k, 1} / G_{k}$. Radi pojednostavljenja proračuna, može se uzeti da je $\eta_{f i}=0,6$.

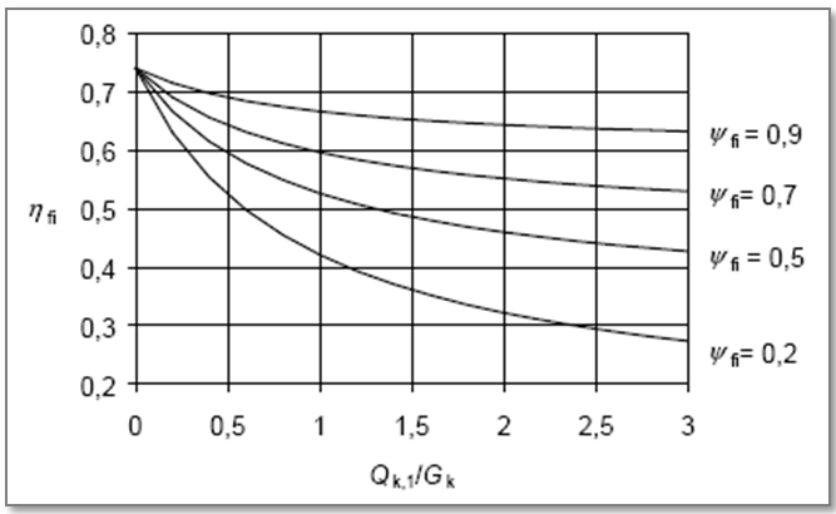

Slika 1 - Očitavanje faktora redukcije ovisno o faktoru kombinacije $\psi_{\mathrm{fi}}$ i omjeru $Q_{k, 1} / G_{k}$

\section{Proračunske vrijednosti karakteristika materijala}

Za potvrdu mehaničke otpornosti potrebno je odrediti proračunske vrijednosti čvrstoće $f_{d, f} i$ krutosti materijala $S_{d, f i}$ prema sljedećim izrazima:

$$
f_{d, f i}=k_{\bmod , f i} \cdot \frac{f_{20}}{\gamma_{M, f i}}
$$




$$
S_{d, f i}=k_{\bmod , f i} \cdot \frac{S_{20}}{\gamma_{M, f i}}
$$

Način uzimanja modifikacijskog faktora $k_{\text {mod,fi }} u$ proračun biti će objašnjen kasnije. Dvadeset-postotni fraktil čvrstoće $\mathrm{f}_{20}$ dobije se tako da se faktor redukcije $k_{\mathrm{f}}$ množi s karakterističnom čvrstoćom pri običnoj temperaturi $\mathrm{f}_{\mathrm{k}}$. Sukladno tome, $\mathrm{S}_{20}$ se dobije množenjem $\mathrm{k}_{\mathrm{fi}} \mathrm{S}$ pet postotnim fraktilom krutosti $\mathrm{S}_{05}$ (modul elastičnosti ili modul posmika) pri običnoj temperaturi. Preporučena vrijednost parcijalnog faktora sigurnosti za drvo tijekom djelovanja požara iznosi $\gamma_{\mathrm{M}, \mathrm{i}}=1,0$, ali se ta vrijednost može posebno definirati u nacionalnom dodatku pojedine države.

\section{Tablica 1 - Vrijednosti faktora redukcije $\mathbf{k}_{\mathrm{fi}}$}

\begin{tabular}{|l|c|}
\hline & $\mathbf{k}_{\mathbf{f i}}$ \\
\hline Monolitno drvo & 1,25 \\
\hline Lijepljeno lamerirano drvo & 1,15 \\
\hline Paneli na osnovi drveta & 1,15 \\
\hline LVL & 1,10 \\
\hline
\end{tabular}

\section{Dubina pougljenja}

Izloženost požaru drvenog elementa ima kao posljedicu pougljenje drva odnosno smanjenje proračunskog poprečnog presjeka. Dubina pougljenja je udaljenost između vanjske površine elementa prije požara te ruba elementa u određenom trenutku trajanja požara. Ona se mora uzeti u obzir pri proračunu svih drvenih površina i panela na osnovi drveta koji su direktno izloženi vatri, te pri proračunu površina koje su prethodno zaštićene protupožarnim oblogama.

\subsection{Proračun nezaštićenih površina}

Pri proračunu nezaštićenih površina razlikuju se dva slučaja: kada je element izložen toplini samo s jedne strane (jednodimenzionalno pougljenje) te kada je element izložen toplini s više strana. U prvom slučaju računa se dubina pougljenja $\mathrm{d}_{\text {char }, 0}$ (udaljenost između vanjske površine drvenog elementa i linije pougljenja), a u drugom se slučaju uvodi fiktivna nominalna dubina pougljenja $d_{\text {charn }}$ (pogledati sliku 2). Dubina pougljenja se dobije tako da se brzina pougljenja $\beta_{0}$ množi s vremenom trajanja izloženosti požaru $t$, dok se $d_{c h a r, n}$ dobije na isti način, samo što se uzima fiktivna proračunska brzina pougljenja $\beta_{n}$. Vrijednosti $\beta_{0}$ i $\beta_{n}$ dane su u tablici 2.
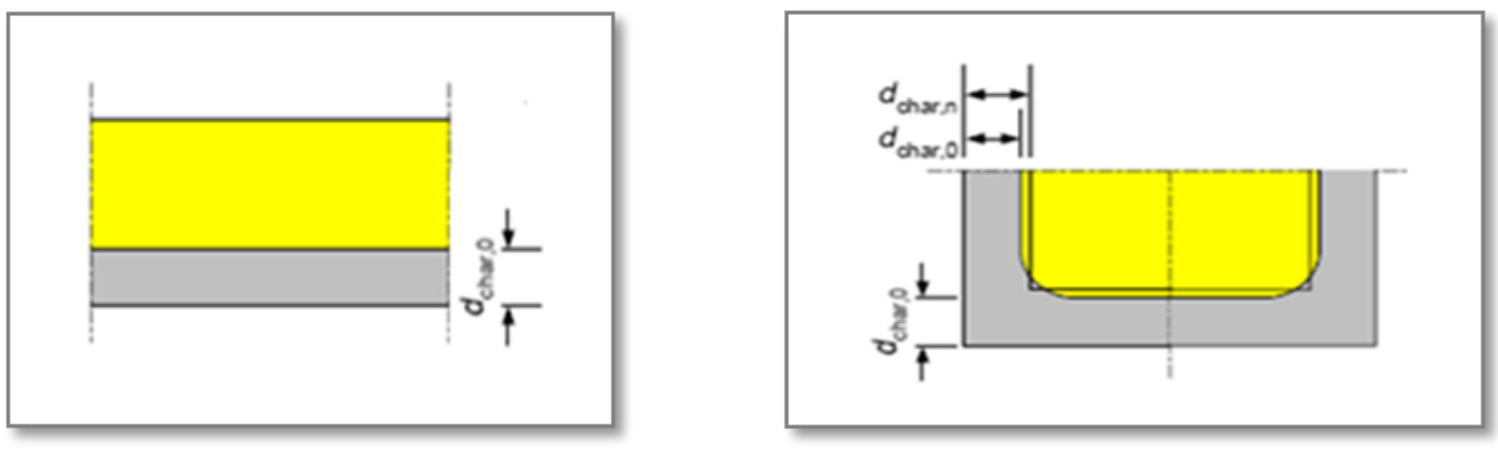

Slika 2 - Dubina pougljenja $d_{c h a r, 0}$ i nominalna dubina pougljenja $d_{c h a r, n}$ 
Jednodimenzionalna proračunska brzina pougljenja se koristi kod proračuna poprečnog presjeka ako je zadovoljen uvjet minimalne potrebne širine poprečnog presjeka $b_{\min }$. Uvjet je dan izrazom:

$$
b_{\min }=\left\{\begin{array}{ll}
2 \cdot d_{\text {char }, 0}+80 & \text { za } d_{\text {char }, 0} \geq 13 \mathrm{~mm} \\
8.15 \cdot d_{\text {char }, 0} & \text { za } d_{\text {char }, 0}<13 \mathrm{~mm}
\end{array}\right\}
$$

\section{Tablica 2 - Proračunske brzine pougljenja $\beta_{0}$ i $\beta_{n}$, ovisno o vrsti i gustoći drveta}

\begin{tabular}{|l|l|c|c|}
\hline & \multicolumn{1}{|c|}{$\begin{array}{c}\beta_{0} \\
{[\mathrm{~mm} / \mathrm{min}]}\end{array}$} & $\begin{array}{c}\beta_{\mathrm{n}} \\
{[\mathrm{mm} / \mathrm{min}]}\end{array}$ \\
\hline \multirow{2}{*}{ a) } & $\begin{array}{l}\text { Meko drvo i bukva } \\
-\quad \text { LLD karakteristične gustoće } \geq 290 \mathrm{~kg} / \mathrm{m}^{3} \\
-\quad \text { monolitno drvo karakteristične gustoće } \geq 290 \mathrm{~kg} / \mathrm{m}^{3}\end{array}$ & 0,65 & 0,7 \\
\hline \multirow{2}{*}{ b) } & \begin{tabular}{l} 
Tvrdo drvo $\quad \begin{array}{l}\text { monolitno ili LLD karakteristične gustoće } 290 \mathrm{~kg} / \mathrm{m}^{3} \\
-\quad \text { monolitno ili LLD karakteristične gustoće } \geq 450 \mathrm{~kg} / \mathrm{m}^{3}\end{array}$ \\
\cline { 2 - 4 }
\end{tabular} & 0,65 & 0,8 \\
\hline c) & $\begin{array}{l}\text { LVL } \\
\text { karakteristične gustoće } \geq 480 \mathrm{~kg} / \mathrm{m}^{3}\end{array}$ & 0,65 & 0,7 \\
\hline & $\begin{array}{l}\text { Paneli } \\
\text { drveni paneli } \\
\text { d) }\end{array}$ & $\begin{array}{l}\text { iverice, furnirske ploče } \\
\text { karakteristične gustoće } 450 \mathrm{~kg} / \mathrm{m}^{3} \text { i de ljine } 20 \mathrm{~mm}\end{array}$ & 0,65 \\
\cline { 2 - 4 } & 0,9 & 0,7 \\
\hline
\end{tabular}

Dakle, za drvo unutar skupina od a) do d) vrijede brzine pougljenja iz tablice 2. Za drugačije gustoće i debljine ploča $h_{p}$ manje od $20 \mathrm{~mm}$, brzina pougljenja računa se prema:

$$
\begin{aligned}
& \beta_{0, \rho, t}=\beta_{0} \cdot k_{\rho} \cdot k_{h} \\
& k_{\rho}=\sqrt{\frac{450}{\rho_{k}}} \\
& k_{h}=\min \left\{\begin{array}{l}
\sqrt{\frac{20}{h_{p}}} \\
1,0
\end{array}\right\}
\end{aligned}
$$

pri čemu je $\rho_{k}$ karakteristična gustoća $u \mathrm{~kg} / \mathrm{m}^{3}$.

\subsection{Proračun zaštićenih površina}

Proračun se provodi za površine zaštićene protupožarnim oblogama, drugim zaštitnim materijalima ili pak drugim konstrukcijskim elementima. Potrebno je izračunati: brzinu pougljenja $\beta_{0}$ ili $\beta_{n}$, vrijeme početka pougljenja protupožarne zaštitne obloge $t_{c h}$, vrijeme otkaza protupožarne zaštitne obloge $t_{f} i$ vremensku granicu $t_{a}$ (vrijeme kada je dubina pougljenja protupožarne zaštitne obloge jednaka $25 \mathrm{~mm}$ ). Brzina pougljenja se određuje za dva slučaja: za stanje prije otkaza protupožarne zaštite, tj. vrijedi da je $t_{c h} \leq t \leq t_{f}$ i za stanje kada je nastupio otkaz protupožarne zaštite, $t j$. vrijedi da je $t_{f} \leq t \leq t_{a}$. U prvom slučaju brzina pougljenja se dobije tako da se vrijednost brzine pougljenja, dana u tablici 2, pomnoži s faktorom $k_{2}$ pri čemu $k_{2}$ ovisi o tipu protupožarne zaštite. Na primjer, ako je drveni element zaštićen gipsanom pločom $u$ jednom sloju, tada se $k_{2}$ računa prema izrazu: 


$$
k_{2}=1-0,018 \cdot h_{p}
$$

gdje je $h_{p}$ debljina sloja u mm. Ako postoji nekoliko slojeva gipsane ploče, tada je $h_{p}$ debljina unutarnjeg sloja. Za stanje nakon otkaza protupožarne zaštite, brzina pougljenja se dobije tako da se vrijednost brzine pougljenja dana u tablici 2 pomnoži s faktorom $k_{3}$, pri čemu je $k_{3}=2$. Kada je $t \geq t_{a}$, brzina pougljenja je jednaka brzini pougljenja dana u tablici 2 , tj. $\mathrm{k}_{3}=0$.

Vrijeme početka pougljenja $t_{c h}$ proračunava se ovisno o vrsti protupožarne zaštite. Na primjer, ako protupožarnu zaštitu čini jedan ili nekoliko slojeva panela na bazi drveta ili drvenih panela, vrijeme početka pougljenja protupožarne zaštite drvenog elementa računa se kao omjer debljine panela $h_{p}$ i brzine pougljenja $\beta_{0}$. Nakon što je određena brzina pougljenja i vrijeme početka pougljenja, određuje se vrijeme otkazivanja protupožarne zaštitne obloge tf prema sljedećem izrazu:

$$
t_{f}=\frac{h_{p}}{\beta_{0}}-t_{r}
$$

gdje je $t_{r}$ vrijeme u minutama ( uzima se da je $t_{r}=4 m i n$ ). Kod određivanja vrijednosti $t_{a}$ razlikuju se dva slučaja: kada je vrijeme početka pougljenja jednako vremenu otkaza zaštite, $t_{c h}=t_{f}$, $i$ kada je vrijeme početka pougljenja manje od vremena kolapsa zaštite, $t_{c h}<t_{f}$. $U$ prvom slučaju $t_{a}$ ovisi o dubini pougljenja. Razlikujemo kada je dubina pougljenja najmanje $25 \mathrm{~mm}$ i kada je ona manja od $25 \mathrm{~mm}$. Vremenska granica $\mathrm{t}_{\mathrm{a}}$ se računa na sljedeći način:

$$
t_{a}=2 \cdot t_{f}
$$

ili

$$
t_{a}=\frac{25}{k_{3} \cdot \beta_{n}}+t_{f}
$$

Mjerodavna je manja vrijednost. U drugom slučaju ta se računa prema sljedećem izrazu:

$$
t_{a}=\frac{25-\left(t_{f}-t_{c h}\right) \cdot k_{2} \cdot \beta_{n}}{k_{3} \cdot \beta_{n}}+t_{f}
$$

\section{Metoda proračunskog poprečnog presjeka}

Norma EN 1995-1-2 nudi dvije metode za proračun poprečnog presjeka. Najjednostavnija i najkorištenija metoda je metoda proračunskog poprečnog presjeka. Računa se s proračunskim poprečnim presjekom za koji se uzima da mu je čvrstoća i krutost pod djelovanjem požara jednaka čvrstoći i krutosti kada požar ne djeluje pa je modifikacijski faktor $k_{\text {mod,fi }}=1$. Utjecaj požara uzima se u obzir tako da se „ukloni“ 7 milimetara debeli sloj početnog poprečnog presjeka $\left(\mathrm{d}_{0}=7 \mathrm{~mm}\right)$. Proračunski poprečni presjek se računa na sljedeći način:

$$
d_{e f}=d_{c h a r, n}+k_{0} \cdot d_{0}
$$

Za zaštićene površine kada je $t_{c h}>20$ min, pretpostavlja se da se faktor $k_{0}$ mijenja linearno od 0 do 1 tijekom vremenskog intervala od $t=0$ do $t=t_{c h}$ (pogledati sliku 4). Za zaštićene površine kada je $t_{c h} \leq 20$ min, primjenjuje se tablica 3 (pri čemu je tifireq zahtijevano vrijeme protupožarne otpornosti u standardnom izlaganju požaru). 
Tablica 3 - Određivanje faktora $k_{\circ}$ za nezaštićene površine

\begin{tabular}{|c|c|}
\hline Vrijeme [min] & $\mathbf{k}_{\mathbf{o}}$ \\
\hline $\mathrm{t}_{\mathrm{f}, \text { req }}<20$ & $\frac{\mathrm{t}_{\mathrm{fi}, \text { req }}}{20}$ \\
\hline $\mathrm{t}_{\mathrm{f} \text {, req }} \geq 20$ & 1,0 \\
\hline
\end{tabular}

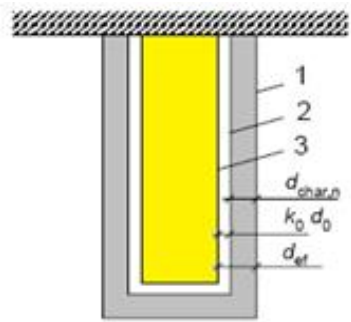

1 - inicijalna (početna) površina elementa

2 - granica preostalog poprečnog presjeka

3 - granica djelotvornog poprečnog presjeka

Slika 3 - Definiranje preostalog i proračunskog poprečnog presjeka

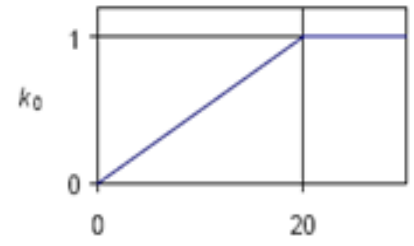

vrijeme u minutama

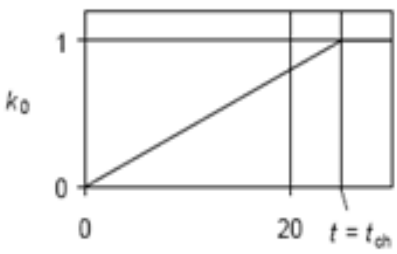

vrijeme u minutama a)

b)

Slika 4 - Varijacije faktora $\mathrm{k}_{\mathrm{o}} \mathrm{za}$ a) nezaštićene elemente $\mathrm{i}$ zaštićene elemente kada je $t_{c h} \leq 20$ min, i za b) zaštićene elemente kada je $t_{c h}>20$ min

\section{Metoda redukcije svojstava}

Metoda opisuje način proračuna proračunskog poprečnog presjeka mekog drveta koji je izložen požaru s tri ili četiri strane. Zasniva se na tome da se, ovisno o temperaturi, pomoću faktora modifikacije $k_{\text {mod,i }}$ smanjuje vrijednost čvrstoće na savijanje, tlačne i vlačne čvrstoće te modula elastičnosti. Smanjenje se može očitati iz dijagrama 1 i 2 [9]. Osim dijagrama, mogu se koristiti i formule dane u normi EN 1995-1-2.

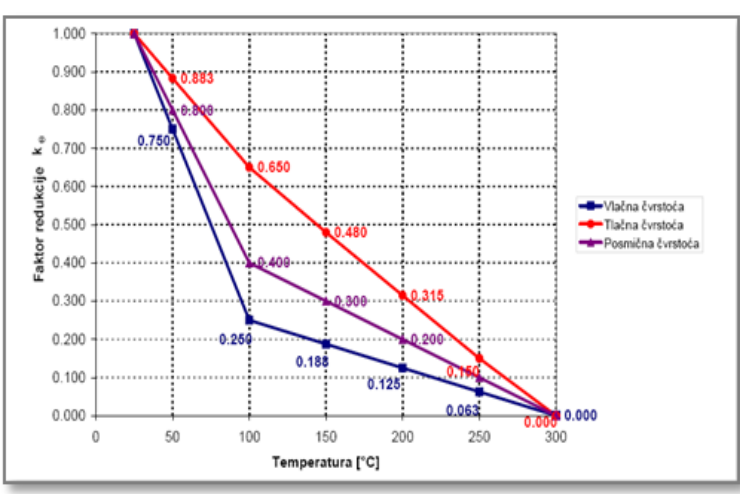

Dijagram 1 - Dijagram redukcije čvrstoće pri
određenim temperaturama

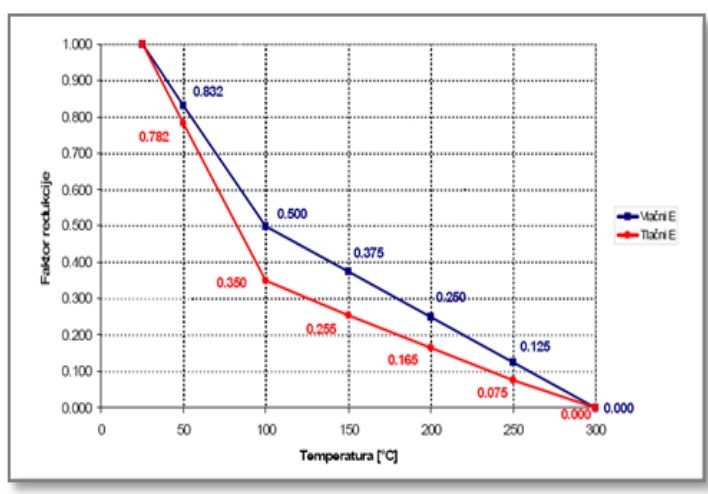

Dijagram 2 - Dijagram redukcije modula elastičnosti pri određenim temperaturama

\section{Računski primjer}

U računskom primjeru će se usporediti dva poprečna presjeka. Prosta greda rapona 10 metara s poprečnim presjekom $b / h=20 / 50$ te prosta greda s poprečnim presjekom $b / h=22 / 66$. Korišteno je LLD klase GL32k. Greda 
je opterećena stalnim jednolikim kontinuiranim opterećenjem od $4 \mathrm{kN} / \mathrm{m}^{2}$ i promjenjivim opterećenjem od 5 $\mathrm{kN} / \mathrm{m}^{2}$. Napravljena je kombinacija opterećenja tako da se stalno opterećenje množilo s parcijalnim faktorom 1,35 , a promjenjivo s 1,50. Dobiven je najveći momenta savijanja u sredini raspona vrijednosti $\mathrm{M}_{\mathrm{y}, \mathrm{Ed}}=161,25$ kNm. Prvo je dimenzionirana greda za stanje kada požar ne djeluje, a postupak je prikazan tablicom 4.

\section{Tablica 4 - Dokaz otpornosti na savijanje kada ne djeluje požar}

\begin{tabular}{|c|c|}
\hline Poprečan presjek b/h=20/50 & Poprečan presjek b/h=22/66 \\
\hline$k_{h}=\min \left\{\begin{array}{l}\left(\frac{600}{h}\right)^{0.1} \\
1.1\end{array}\right\}=\left\{\begin{array}{l}\left(\frac{600}{500}\right)^{0.1} \\
1.1\end{array}\right\}=\left\{\begin{array}{l}1.018 \\
1.1\end{array}\right\}$ & $k_{h}=1.0$ \\
\hline$f_{m, y, d}=f_{m, z, d}=\frac{0.9 \cdot 3.2 \cdot 1.018}{1.25}=2.346 \mathrm{kN} / \mathrm{cm}^{2}$ & $f_{m, y, d}=f_{m, z, d}=\frac{0.9 \cdot 3.2 \cdot 1}{1.25}=2.304 \mathrm{kN} / \mathrm{cm}^{2}$ \\
\hline$W_{y}=\frac{b \cdot h^{2}}{6}=\frac{20 \cdot 50^{2}}{6}=8333.33 \mathrm{~cm}^{3}$ & $W_{y}=\frac{b \cdot h^{2}}{6}=\frac{22 \cdot 66^{2}}{6}=15972 \mathrm{~cm}^{3}$ \\
\hline$\sigma_{m, y, d}=\frac{M_{y, d}}{W_{y}}=\frac{161.25 \cdot 100}{8333.33}=1.935 \mathrm{kN} / \mathrm{cm}^{2}$ & $\sigma_{m, y, d}=\frac{M_{y, d}}{W_{y}}=\frac{161.25 \cdot 100}{15972}=1.01 \mathrm{kN} / \mathrm{cm}^{2}$ \\
\hline$\frac{\sigma_{m, y, d}}{f_{m, y, d}}=\frac{1.935}{2.346} \leq 1$ & $\frac{\sigma_{m, y, d}}{f_{m, y, d}}=\frac{1.01}{2.304} \leq 1$ \\
\hline $0.825<1 \rightarrow$ iskorištenost presjeka: $82,5 \%$ & $0.438<1 \rightarrow$ iskorištenost presjeka: $43,8 \%$ \\
\hline
\end{tabular}

Proračun za požarno stanje prema normi EN 1995-1-2 provest će se po metodi reduciranog poprečnog presjeka. Prvo se računa dubina pougljenja za svakih 15 minuta trajanja požara. Pomoću dobivenih vrijednosti vrši se usporedba minimalne širine poprečnog presjeka i zadane $\left(b_{\min }<b\right)$. Zatim se određuje proračunski poprečni presjek $d_{\text {ef }}$ prema izrazu (12). $U$ izrazu se uzima da $k_{0}$ iznosi 1 jer $t_{f, r e q}$ iznosi 120 minuta, a $d_{0}$ iznosi $7 \mathrm{~mm}$. Proračunska visina $h_{\text {ef }} \mathrm{i}$ širina $b_{\text {ef }}$ računa se prema sljedećim izrazima:

$$
\begin{aligned}
& h_{e f}=h-d_{e f} \\
& b_{e f}=b-2 \cdot d_{e f}
\end{aligned}
$$

Također, potrebno je proračunati proračunsku požarnu čvrstoću $f_{d, f i}$ pomoću fraktila $f_{20}$, pri čemu $k_{f i} z a$ LLD iznosi 1,15 (prema tablici), a za $f_{k}$ je uzeto $f_{k}=f_{m, k}=32 \mathrm{~N} / \mathrm{mm}^{2}$. Tako $f_{20}$ iznosi $3,68 \mathrm{kN} / \mathrm{cm}^{2}$, a f f,fiznosi $3,68 \mathrm{kN} / \mathrm{cm}^{2}$. Sada se može izračunati omjer naprezanja u presjeku za pojedinu vrijednost vremena $t$ i požarne čvrstoće poprečnog presjeka. Pritom se naprezanje dobije kao omjer reducirane vrijednosti momenta savijanja i momenta otpora W. Rezultati su prikazani u tablici 5. 
Tablica 5 - Dokaz nosivosti kada djeluje požar

\begin{tabular}{|c|c|c|c|c|}
\hline \multicolumn{5}{|c|}{ Poprečan presjek b/h=20/50 } \\
\hline $\begin{array}{c}t \\
{[\mathrm{~min}]}\end{array}$ & $\begin{array}{c}\mathbf{A} \\
{\left[\mathbf{c m}^{2}\right]}\end{array}$ & $\begin{array}{c}\mathbf{W} \\
{\left[\mathbf{c m}^{3}\right]}\end{array}$ & $\begin{array}{c}\boldsymbol{\sigma}_{\mathrm{y}, \mathrm{d}} \\
{\left[\mathbf{k N}^{2} \mathbf{c m}^{2}\right]}\end{array}$ & $\frac{\sigma_{\mathrm{y,d}}}{\mathbf{f}_{\mathrm{d}, \mathrm{fi}}} \leq 1$ \\
\hline 15 & 824,5 & 6664,71 & 1,452 & $0,394<1$ \\
\hline 30 & 696,05 & 5492,96 & 1,761 & $0,478<1$ \\
\hline 60 & 490,32 & 3710,09 & 2,608 & $0,709>1$ \\
\hline 75 & 393,16 & 2911,03 & 3,323 & $0,903>1$ \\
\hline 90 & 299,81 & 2171,09 & 4,456 & $\mathbf{1 , 2 1 1}>\mathbf{1}$ \\
\hline 105 & 210,25 & 1488,40 & 6,500 & $\mathbf{1 , 7 6 6}>\mathbf{1}$ \\
\hline 120 & 124,5 & 861,125 & 11,235 & $\mathbf{3 , 0 5 3}>\mathbf{1}$ \\
\hline
\end{tabular}

\begin{tabular}{|c|c|c|c|c|}
\hline \multicolumn{5}{|c|}{ Poprečan presjek b/h=22/66 } \\
\hline $\begin{array}{c}\mathrm{t} \\
{[\mathrm{min}]}\end{array}$ & $\begin{array}{c}\mathbf{A} \\
{\left[\mathbf{c m}^{2}\right]}\end{array}$ & $\begin{array}{c}\mathbf{W} \\
{\left[\mathbf{c m}^{3}\right]}\end{array}$ & $\begin{array}{c}\boldsymbol{\sigma}_{\mathrm{y,d}} \\
{\left[\mathbf{k N}^{\mathbf{c}} \mathbf{c m}^{2}\right]}\end{array}$ & $\begin{array}{c}\sigma_{\mathrm{y,d}} \\
\mathrm{f}_{\mathrm{d}, \mathrm{fi}}\end{array}$ \\
\hline 15 & 1225,5 & 13174,13 & 0,734 & $0,199<1$ \\
\hline 30 & 1057,9 & 11170,14 & 0,866 & $0,235<1$ \\
\hline 60 & 785,92 & 8042,58 & 1,203 & $0,327<1$ \\
\hline 75 & 655,61 & 6602,55 & 1,465 & $0,398<1$ \\
\hline 90 & 529,11 & 5242,55 & 1,845 & $0,502<1$ \\
\hline 105 & 406,40 & 3960,72 & 2,443 & $0,664<1$ \\
\hline 120 & 287,5 & 2755,21 & 3,511 & $\mathbf{0 , 9 5 4}<1$ \\
\hline
\end{tabular}

Na kraju su dana dva dijagrama (dijagrami 3 i 4) koja pokazuju odnos vremena $t$ i naprezanja $\sigma_{y, m, d}$ za oba promatrana presjeka.

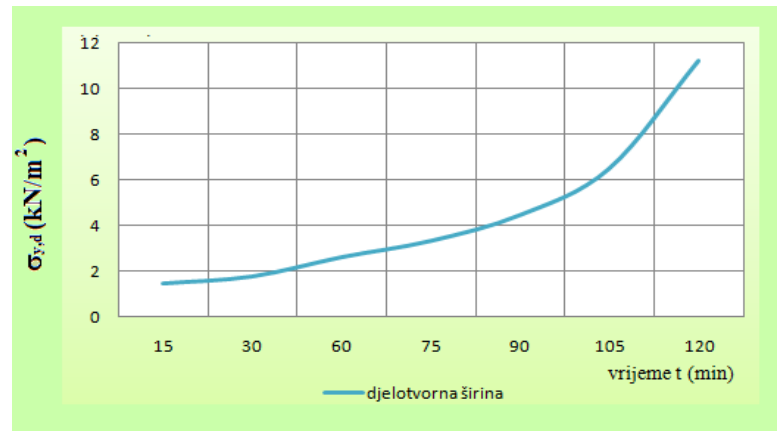

Dijagram 3 - Odnos vrijeme / naprezanje za poprečan presjek $b / h=20 / 50$

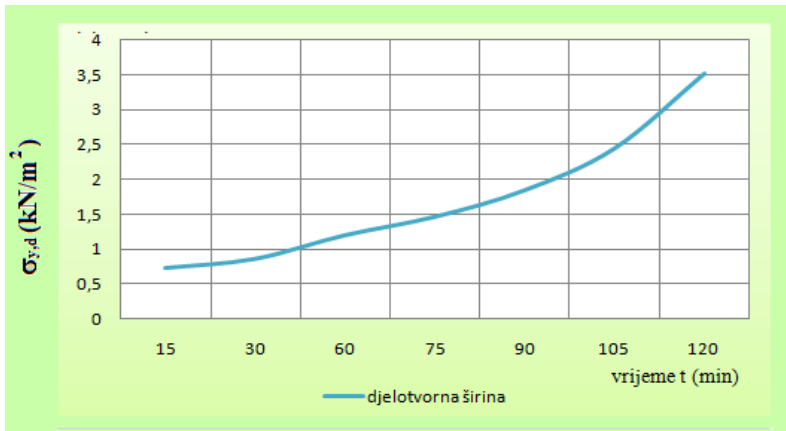

Dijagram 4 - Odnos vrijeme / naprezanje za poprečan presjek $b / h=22 / 66$

\section{Zaključak}

Napravljen je proračun protupožarne otpornosti proste grede prema metodi proračunskog poprečnog presjeka. Rezultati su pokazali da poprečan presjek koji ima vrlo visok postotak iskorištenosti prema graničnom stanju nosivosti (otpornost na savijanje), gubi nosivost nešto prije od 90 minuta izloženosti požaru, tj. u trenutku kada je $\mathrm{t}=90$ min dobiven je omjer naprezanja i požarne otpornosti 1,211. $S$ druge strane, poprečan presjek koji nema visoku iskorištenost prema graničnom stanju nosivosti $(43,8 \%)$, može nositi tijekom standardnog požara u trajanju od 120 minuta. Kao uputa preliminarnom odabiru dimenzija poprečnog presjeka, a vezano za protupožarnu otpornost, pri proračunu GSN može se postaviti granica od 80-tak \% iskorištenosti presjeka na savijanje (ako je dovoljna F60 požarna otpornost). Također se vidi kako prirast naprezanja u vremenu nakon 80-tak minuta izloženosti poprima oblik krivulje drugog reda, odnosno puno brže raste, što se može postaviti kao optimalna granica za nezaštićene elemente izložene požaru. 


\section{Literatura}

[1] Žagar, Z. 2006: Drvene konstrukcije, 2. dio

[2] Bjelanović, A.; Rajčić, V. 2005: Drvene konstrukcije prema europskim normama

[3] König, J.; Winter S. 2004: The Eurocode 5 Fire part - EN 1995-1-2, http://www.ewpa.com/Archive/2004/jun/Paper_120.pdf.

[4] Just, A. 2005: Eurocode 5 Design of fire resistance of timber structures, http://www.fsuw.com/fsuw/project_fileview?fld=85\&id=Alar_Just_Eurocode_5_1_2.pdf

[5] CEN-European Commitee for Standardization (2009): EN 1995-1-2:2004, Eurocode 5 - Design of timber structures - Part 1-2: General - Structural fire design

[6] Cachim, P. B.; Franssen. J. 2010: Assessment of Eurocode 5 charring rate calculation methods, Fire Technology, 46, 169-181.

[7] Education and Culture Leonardo da Vinci 2008: Fire resistance of timber structures, Handbook 1- Timber structures, Chapter No. 17, Graz, September 2008.

[8] Karakteristike LLD, http://drvene-konstrukcije.hr/konstrukcije-od-Ilda/karakteristike-Ild/

[9] Peroš, B.; Boko, I. 2009: Otpornost konstrukcija na požar, http://stari.gradst.hr/ pavasic/Strucno/Strucno_usavrsavanje_02_04_2009-Boko.pdf 